\title{
DEVELOPMENT OF THE METHOD FOR ASSESSING THE COVERED CONDUCTORS STATE DUE TO ELECTRICAL AGEING IN MOIST AND HIGHLY POLLUTED ENVIRONMENTS
}

\author{
Ю.В. Солобьев, А.Н. Назаричеб, А.И. Таджибаеб
}

\begin{abstract}
МЕТОД ОЦЕНКИ СОСТОЯНИЯ ЗАЩИЩЕННЫХ ПРОВОДОВ ПРИ ЭЛЕКТРИЧЕСКОМ СТАРЕНИИ В УСЛОВИЯХ ПОВЫШЕННЫХ ЗАГРЯЗНЕНИЙ И УВЛАЖНЕНИЙ
\end{abstract}

\begin{abstract}
Based on field experience, the paper has proved the practical importance of finding a solution for condition assessment of covered conductors due to electrical ageing under moisture and pollution. The analysis of combined impacts with respect to construction and material properties on tracking erosion of covered conductor and plastic components of OHL accessories was performed for the first time ever. A highvoltage laboratory setup for accelerated ageing tests was designed. A detailed description of the test method is given. We have developed a method for assessing the technical conditions, based on measuring the leakage current. The given diagnostic parameter provides the opportunity to its wide application within diagnostic procedures for condition assessment during electrical ageing in moist and polluted environments. COVERED CONDUCTOR; CONDITION ASSESSMENT, POLLUTION; MOISTURE; ELECTRICAL AGEING; LEAKAGE CURRENT.
\end{abstract}

\begin{abstract}
Обоснована практическая важность решения задачи оценки технического состояния защищенных проводов в условиях электрического старения при повышенных загрязнениях и увлажнениях. Впервые проведен анализ комбинированного воздействия различных факторов на интенсивность развития трекинговой эрозии защищенных проводов, а также пластиковых элементов линейной арматуры с учетом особенностей конструкций и свойств применяемых материалов. Разработана лабораторная высоковольтная установка и методика проведения ускоренных испытаний на электрическое старение защищенных проводов при воздействии солевого тумана, моделирующего загрязнения. Предложен метод оценки состояния защищенных проводов на основе измерения поверхностных токов утечки. Определен безразмерный диагностический признак, а также обоснована возможность универсального его применения в задачах оценки состояния защищенных проводов при их электрическом старении.
\end{abstract}

ЗАЩИЩЕННЫЙ ПРОВОД; ТЕХНИЧЕСКОЕ СОСТОЯНИЕ; ЗАГРЯЗНЕНИЕ; УВЛАЖНЕНИЕ; ЭЛЕКТРИЧЕСКОЕ СТАРЕНИЕ; ТОК УТЕЧКИ.

Studied experience of operation and maintenance of 10-35 kV overhead lines (OHL) in different countries has shown the significant influence of moisture intensity and environment pollution level on the rate of electrical degradation and erosion of covered conductors (CC) [1-5]. Due to high electric field strength accelerated ageing of polymeric covering material takes place. It leads to high fault indexes on OHL and limits CC lifetime. The intensity of moisture penetration and environment pollution level significantly influence on rates of defects concentration and its growth inside $\mathrm{CC}$ un- der combined electric and mechanical loads on OHL. In this case servicemen from power network utilities are faced to the actual needs for diagnostic of CC for earlier detection of defects with aspects to operating conditions on OHL.

Intensive processes of tracking erosion of $\mathrm{CC}$ under moisture and heavy pollution conditions are locally observed nearby of accessories fixing $\mathrm{CC}$ to pole insulators. The fact is that there is a high concentration of non-uniform electric field with high strength. Besides there are a number of design factors forming suitable conditions for high local distribution of electrical 
charges under combined high electric field stresses, humidity and pollution levels:

1) floating electrical potentials along $\mathrm{CC}$ surface leading to surface discharges and forming conductive carbon paths within XLPE (cross-linked polyethylene) covering;

2) electrical charges between insulation materials with different dielectric permittivity. As example, it can be due to the installation of ceramic post insulators on OHL in environment with high humidity and pollution levels. Particularly, dielectric permittivity of XLPE covering and traditional ceramic post insulators differs in three times;

3) metal parts of insulators and fitting accessories for CC. The use of floating helical fittings can cause surface tracking of XLPE sheathed conductor in coastal environments $[4,10]$. The combined use of piercing clamps and floating helical fittings leads to forming of non-uniform electrical potentials distribution along CC. These accessories from electrical point of view can be considered as secondary electrodes charging with electrostatic voltage. It provides the forming of leakage currents along CC surface. As result, tracking erosion of XLPE sheathed conductors takes place (fig.1, a).

a)

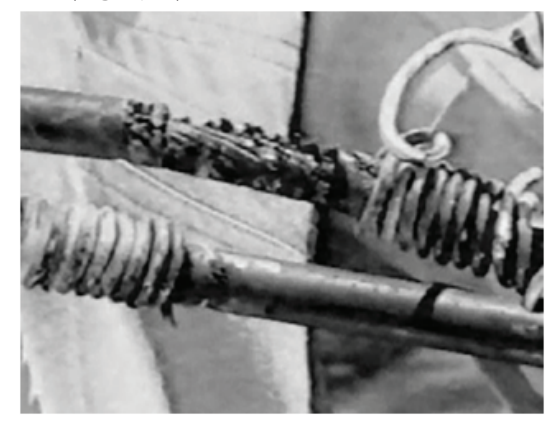

b)

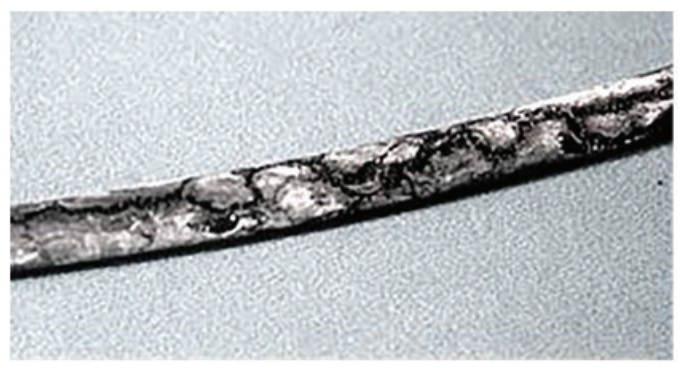

Fig. 1. Tracking erosion of $\mathrm{CC}$ close to:

$a$ ) fitting accessories; $b$ ) post ceramic insulator

Electrical and thermal effects can lead to damage not only CC but plastic accessories. In this case a low electrical tracking stability of CC can be the reason of decreasing 10-35 kV OHL reliability. For high reliability it is important on design stage to turn attention to environment conditions along $10-35 \mathrm{kV}$
OHL including the existing levels of humidity and pollution. It helps to provide compatible designs of $\mathrm{CC}$ and fitting accessories (incl. materials) with aim to decrease the effect of tracking erosion in heavy environment. Unfortunately, up to now these aspects are not fully considered while OHL design. Moreover, there are no any requirements regarding tracking stability of accessories for CC in European standard EN 50397-2. As to Russia, there is no any standard regarding accessories for OHL with CC. For this reason there are a lot of cases when unsuitable designs of $\mathrm{CC}$ and accessories use. It leads to forming of suitable conditions for tracking erosion of CC in heavy environments.

4) volume content of carbon (\%) in covering material of CC. Carbon is added to polyethylene for increasing of $\mathrm{CC}$ ultraviolet resistance. But it should be noted that carbon as a semiconductor increases the conductivity of covering insulation. It forms the conditions for tracking discharges on the wetted and polluted surface of CC. Therefore, a designer during selection of CC should pay attention to component content of CC covering in terms of carbon quantity. The maximum or minimum volume content of carbon should be defined related to existing environmental conditions along designed OHL route. Unfortunately, the last standard GOST R 31946-2012 [6] regarding the general requirements for CC doesn't consider this aspect. Moreover, this standard (clause 5.2.5) only sets the minimum volume content of carbon inside covering material which equals to $2,5 \%$. It is necessary to note that in mountain areas with clean environment the use of $\mathrm{CC}$ with highest value of volume carbon content inside covering material is suitable. Oppositely, while there is an environment with high levels of humidity and pollution volume carbon content should have minimum value. The existing experience $[7,8]$ abroad has shown that $2,5 \%$ of carbon content is enough for initiation of tracking erosion of $\mathrm{CC}$ operated in moisture and pollution environment (fig. 1, b). The last investigations have shown that volume carbon content significantly influences on specific properties of CC surface [9]. It includes water adsorption and surface wetting ability which are important when CC use on OHL's in areas with high wind and snow loads, temperatures. Increasing wetting ability of $\mathrm{CC}$ surface leads to forming of solid conductive water films and leakage currents;

5) cracks and another defects inside $\mathrm{CC}$ covering. Any outside or inside mechanical damages of CC 
covering can exist during CC operation on OHL under service loads. Also mechanical defects can occur during production, storage, transportation, assembly of CC. Cracks grow due to simultaneous existence of internal defects inside covering material structure and high operating loads on OHL. Under combined impacts of non-uniform electric field, mechanical loads, humidity and pollution the discharges and electrical ageing occur along CC surface with cracks. High intensity of discharge activity leads to tracking erosion of CC with its failure. Also cracks can occur due to missing of adhesion between aluminum core and XLPE covering. It concerns with existing of nonuniform molecular structure in local volumes of polyethylene which are closed to CC core. It is due to production specifics: a size of XLPE volume with possible structure heterogeneities and cracks can be up to $40 \%$. Local missing of adhesion leads to forming of air inclusions and partial discharges under applied operating high voltage. It results in tracking erosion and decreasing of $\mathrm{CC}$ remaining lifetime.

\section{Research problem statement}

Provided analysis has found that considered challenge of CC tracking erosion is not studied enough. It lets us formulate the tasks of performed research with aim to find a diagnostic parameter and use it with developed method for condition assessment of $\mathrm{CC}$ while tracking erosion takes place.

\section{Description of developed experimental installation for laboratory tests}

For laboratory accelerated ageing tests of $\mathrm{CC}$ under combined impacts of moisture and pollution environment an experimental high voltage installation has been developed (fig. 2).

One of features of the test installation is a possibi-lity to provide the aging tests of CC with modeling different environment conditions. It would define the weight ratio of each factor in electrical ageing: intensity of electric field, humidity and pollution levels, different accessories design. Operating voltage is applied to CC under test (CCUT) powered with $\mathrm{SF}_{6}$ transformer type IOG-50. It is possible to provide a control of test voltage and current load. Nominal voltage of transformer primary winding is $220 \mathrm{~V}$. Test voltage is measured with voltage transformer type JDQXF-66. Measurements methods are set in [10].Positions of CCUT are corresponding to operating conditions on OHL. CCUT are installed in a testing room with equipment for modeling salt fog environment and different operating conditions on OHL closed to seaside, zones with high pollution levels, etc. Salt fog environment is formed with spray in the air of aqueous solution of $\mathrm{NaCl}$. It is technically provided with using of special sprayers installed on two opposite walls of test room.

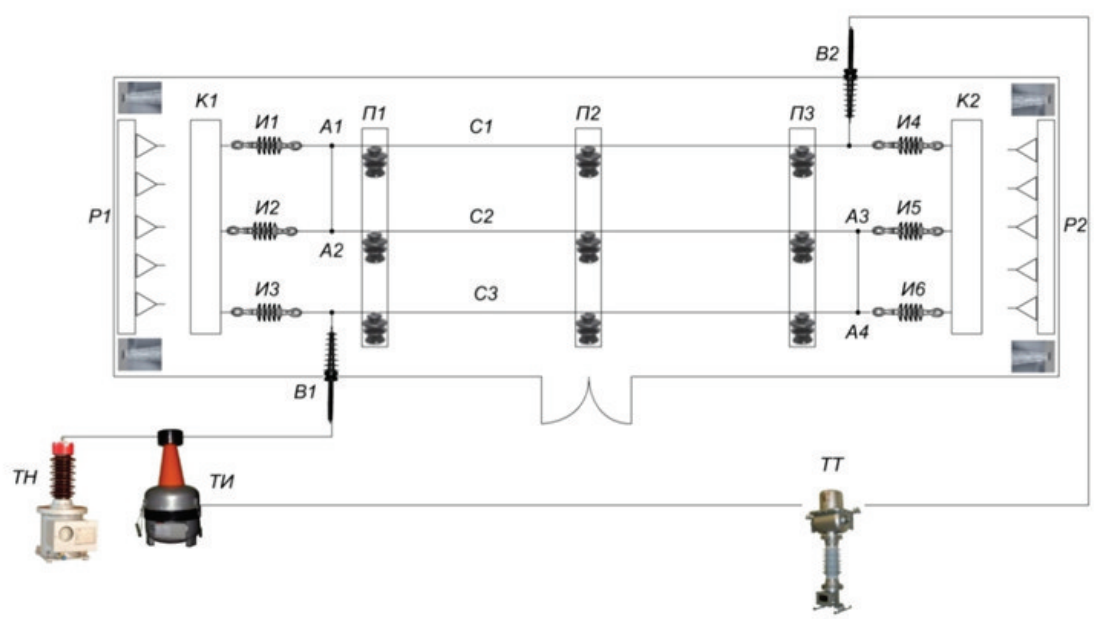

Fig. 2. Schematic drawing of installation for accelerated ageing tests of $10-35 \mathrm{kV}$ covered conductors within wetting and pollution conditions: ТИ - $\mathrm{SF}_{6}$ power supply source type IOG-50; B1, B2 - high voltage bushings; P1, P2 - salt fog spray disperser; K1, К2 - crossarms of end supports; И1-И6 - tension insulators; П1-П3 - crossarms of intermediate supports; C1-C3 - covered conductors under test; A1A2, A3A4 - cross connections for providing closed loop of circuit; $\mathrm{TH}-\mathrm{SF}_{6}$ voltage transformer type

JDQXF-66; TT - $\mathrm{SF}_{6}$ current transformer type TBMO 


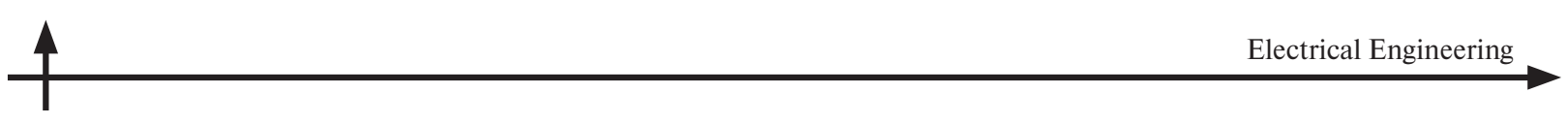

Before testing CCUT's surfaces should be carefully cleaned from any pollution, fats, oils, etc. While cleaning no any damages of CCUT's surfaces should be occurred. To characterize pollution level a salt fog density as a main parameter is considered. The parameter is controlled according to the ratio of specific conductivity of salt solution at current temperature and room temperature. As additional parameter describing the intensity of moisture and pollution impacts on CCUT the consumption of aqueous solution needed for every salt fog sprayer could be considered. During tests the intensity of moisture impact on CCUT in vertical and horizontal planes equals to $1 \mathrm{~mm} / \mathrm{min}$. For every pollution level CCUT of all phases are tested because using of wire links forming the looped circuit for current. Average surface pollution density for CCUTs is $3 \mathrm{mg} / \mathrm{cm}^{2}$. During tests salt fog conductivity at room temperature equals to 202,6 $\mathrm{mSm} / \mathrm{cm}$. It corresponds to solution density equals to $224 \mathrm{~g} / \mathrm{l}$. Overall test duration is 1000 hours. Date of test beginning is on February 18, 2014. Measured leakage current is taken as the main diagnostic indicator for assessment of CC electrical ageing degree. The analysis of latest investigations of tracking stability of polymeric insulation materials for high voltage $\mathrm{OHL}$ applications let to choose a first-to-third harmonics ratio of measured leakage current. Harmonics content is analyzed with using Fourier transform. Leakage current is measured with FLUKE i2000flex (fig. 3).

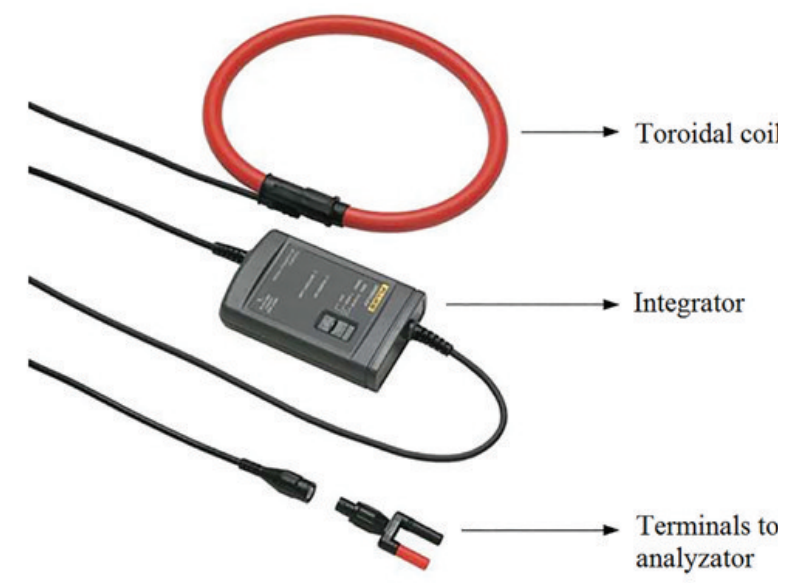

Fig. 3. Instrument for leakage current measurements FLUKE i2000flex

The measuring instrument has a design providing its safe using without throughout electrical connection to CCUT. It consists of a transducer, a toroidal coil and connecting coaxial cable. Toroidal coil has a winding which is fixed on thin plastic tube and coated with insulation material. One output of the winding is constantly connected to integrator. Another one winding output has a temporary connection for measurement of leakage currents without electrical connection. Toroidal coil has a flexible design. Measurement interval is $1 \mathrm{~min}$ with saving results in database consisting of measurement data during 250 cycles of operating current frequency equals to $50 \mathrm{~Hz}$. Fourier analysis of measurement data provided harmonic contents of leakage currents. The first, third and fifth harmonics of leakage currents have been studied for detailed analysis.

\section{Analysis of results}

On the basis of measurement data the comparison of leakage currents through CCUT with its acceptable values when pollution and moisture impacts are lowest is provided. While pollution and moisture impacts are absent the maximum leakage current equals to $0,3 \mathrm{~mA}$ [11]. During tests the visual decoloring of CC surface is observed at leakage currents up to $2-5 \mathrm{~mA}$ (fig. 4). These measured values of leakage currents are the lowest. Graphs of time-dependent fundamental harmonic of measured leakage current during the period from 18 to 21 day after test beginning are shown in fig. 5-7. According to the data fundamental harmonic is being increased from 6-8 $\mathrm{mA}$ up to $10-12 \mathrm{~mA}$ during 10 hours on $18^{\text {th }}$ day of testing. As result, water evaporation and drying of CCUT surface are observed.

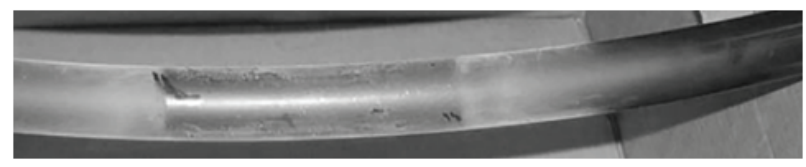

Fig. 4. Visual decoloring of CCUT surface as an initial sign of tracking erosion

Water evaporation from CC surface leads to decreasing leakage current during short time. But then the current increases after increasing of conductivity of pollution layers due to high concentration of salt pollution on CCUT surface. The visible signs of CC tracking erosion are observed after 543 hours of testing (fig. 8). On $21^{\text {th }}$ day of testing fundamental harmonic of leakage current decreases in 3 times and equals to 4-5 mA (fig. 7). 


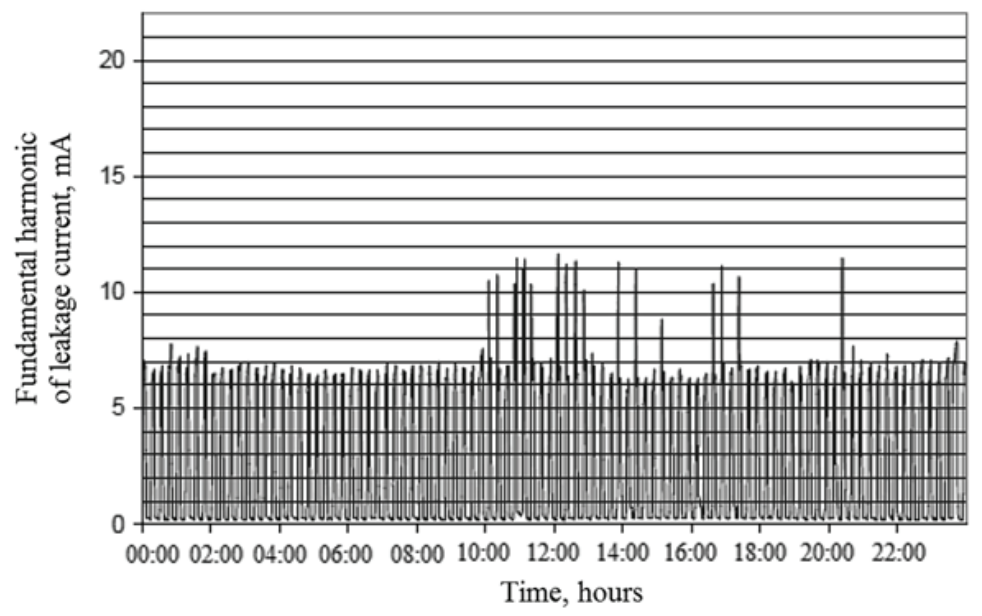

Fig. 5. Time dependent fundamental harmonic of leakage current on $18^{\text {th }}$ day of testing

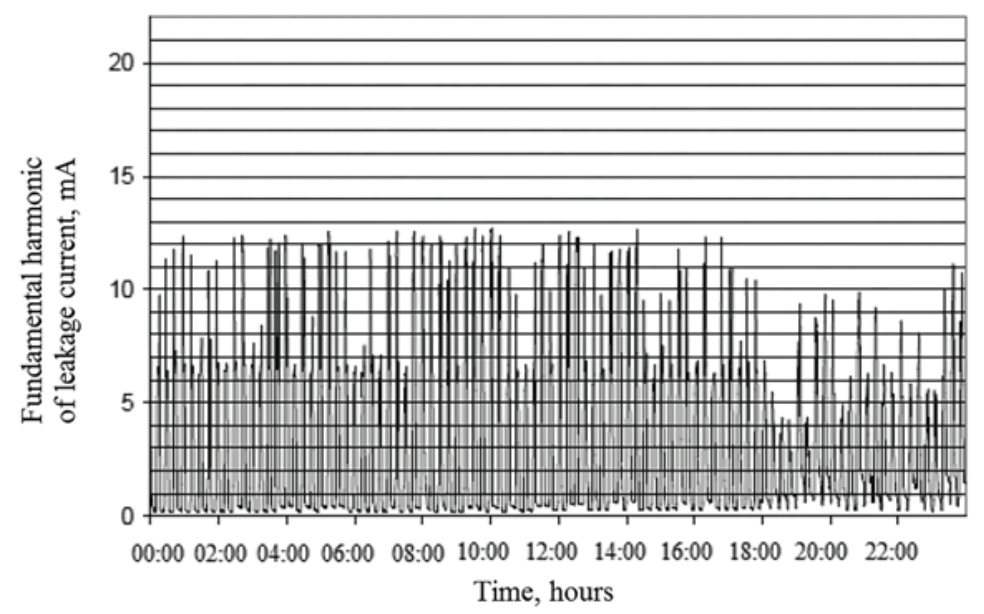

Fig. 6. Time dependent fundamental harmonic of leakage current on $19^{\text {th }}$ day of testing

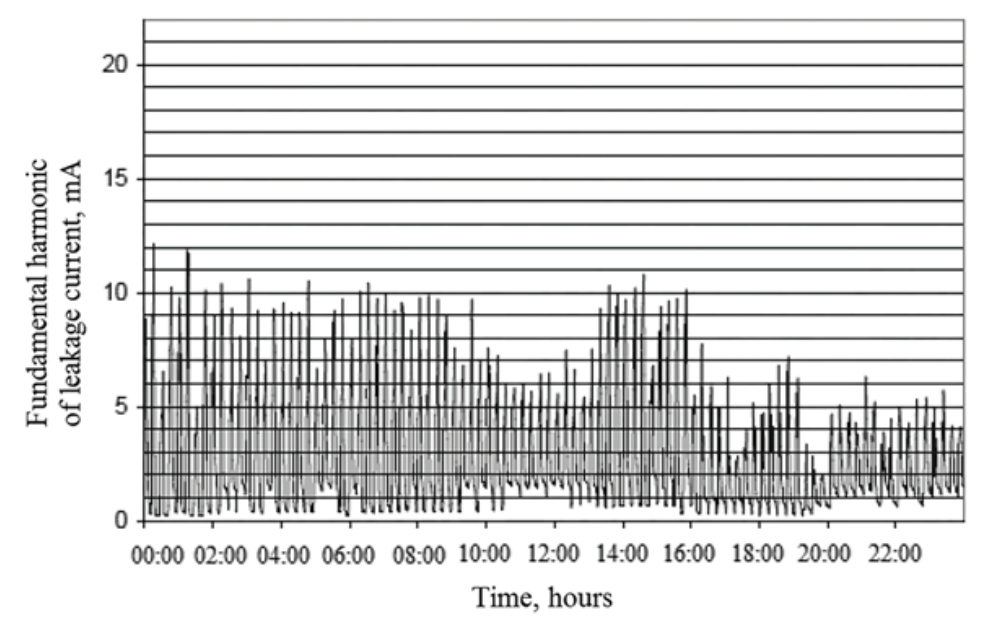

Fig. 7. Time dependent fundamental harmonic of leakage current on $21^{\text {th }}$ day of testing 


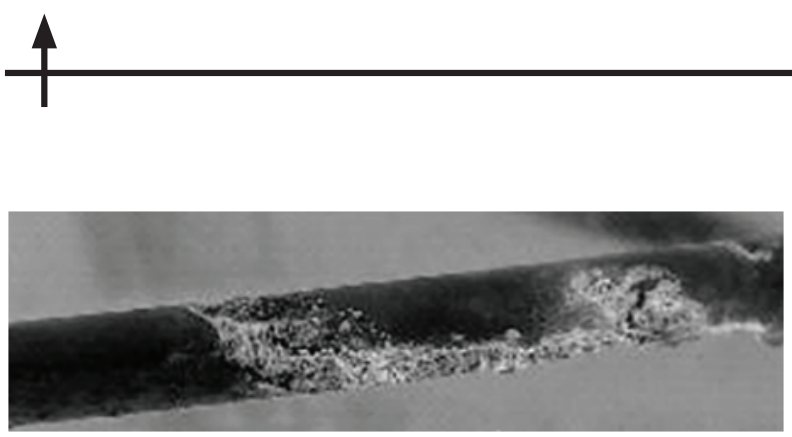

Fig. 8. Visual decoloring of CC surface at maximum leakage current

After Fourier transform the $3^{\text {rd }}$ and the $5^{\text {th }}$ leakage current harmonics are found. Its time dependent functions corresponding to the time interval from $18^{\text {th }}$ to $21^{\text {th }}$ of testing are defined. Analysis of these functions found small changes of the $5^{\text {th }}$ leakage current harmonic in comparison with the $3^{\text {rd }}$ harmonic. Therefore, the $5^{\text {th }}$ harmonic of leakage current is not considered. As a result, a diagnostic parameter equals to the ratio of the $3^{\text {rd }}$ leakage current harmonic to its fundamental harmonic is offered. This diagnostic parameter I3/I1 would be used as an indicator describing technical condition of CC while tracking erosion under combined impacts of high moisture and pollution is observed.

For universal application of diagnostic parameter it is necessary to exclude from consideration its possible deviation depending on the characteristics of measuring equipment. As result, the bands of diagnostic parameter changes are defined. It should be noted that this approach doesn't restrict the use of the parameter. Moreover, the bands let to filter required data from a whole spectrum to assess a technical condition of CC. The marker for restricting the bands of diagnostic parameter changes is based on the frequency of occurring of different values of diagnostic parameter from the bands during tests (fig. 9, 10).

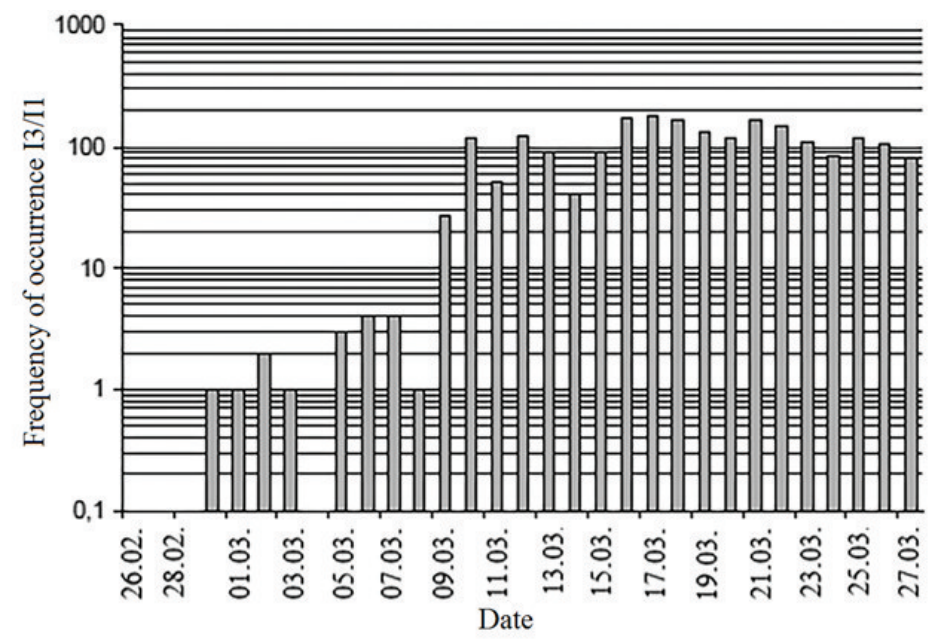

Fig. 9. Frequency of occurring of diagnostic parameter I3/I1 within the band $[0,15 \div 0,20]$ during accelerated ageing tests

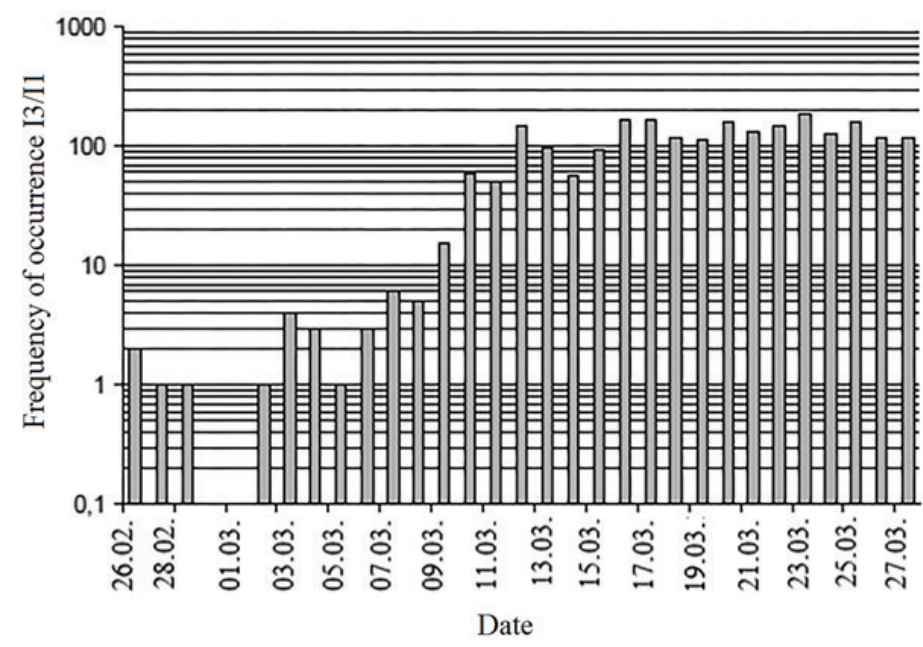

Fig. 10. Frequency of occurring of diagnostic parameter I3/I1 within the band $[0,20 \div 0,25]$ during accelerated ageing tests 
On the basis of known relations the offered marker helps to define the probability of occurring of diagnostic parameter belonging to different bands. It characterizes the dynamic properties of electrical ageing of CC. The analysis of given graphs let to find the similar character in marker changes in two considered bands.

It opens the possibilities for use of diagnostic parameter with the aim to assess a technical state of CC from operation in heavy environment. Fixed time of detection of visual tracking erosion signs of CC during tests correlates with dynamic properties of offered marker. The ageing degree of CC increases with increasing of frequency of diagnostic parameter occurring in two bands.

Given results of the research proves the possibility to use the correlations for assessment of technical condition of CC operating in heavy environment with high moisture and pollution levels.

\section{REFERENCES}

1. Rokowska A. Overhead CC lines experience in design, construction and service with reliability assessment in central Europe. Proc. of the Fourth International Covered Conductor Confrerence ICCC. Helsinki, 2000. P. 56-68.

2. Lovrenčić V. Slovene experience about using covered conductors (PAS system) in Medium Voltage Network. Proc. of International Conference on Electricity Distribution (CIRED 2000). Shanghai, 2000. P. 35-48.

3. Wareing J., Ward A. The tracking performance of $50 \mathrm{~mm} 2$ AMO Kraft BLX Triple compared with XLPE (3\% carbon) sheated conductor using helical fittings. EATL Report T3805. 2001. 80 p.

4. Wareing J. Tracking tests on new and old CC samples from Finland and Sweden. EATL Report 5779. 2004. $75 \mathrm{p}$.

5. Yano K., Wareing J. The Japanese experience. EATL Report 4373. 1997.

6. GOST 31946-2012. Provoda samonesushchiye izolirovannyye i zashchishchennyye dlya vozdushnykh liniy elektroperedachi. Obshchiye tekhnicheskiye usloviya. Vved. 2014-01-01. M.: Standartinform, 2013. 20 s. (rus.)

7. Wald D. The use of track resistant XLPE insulation for MV aerial cables. Proc. of Covered Conductor Seminar. Capenhurst. 1996. P. 18-27.

8. Wald D., Campus A. The influence of carbon black in XLPE compounds in MV aerial cables. Proc. of the 1st International Covered Conductor Confrerence ICCC. Capenhurst, 1997. P. 25-36.

9. Soloviev Iu.V., Tadzhibaev A.I., Nazarythev A.N. Analyz technicheskogo sostoyaniya zaschischennych provodov liniy electroperedachi. Saint-Petersburg: Izdvo PEIPK, 2015. 193 s. (rus)

10. GOST 17512. Elektrooborudovaniye i elektroustanovki na napryazheniye $3 \mathrm{kV}$ i vyshe. Metody izmereniya pri ispytaniyakh vysokim napryazheniyem. Vved. 198401-01. M.: IPK Izd-vo standartov, 1984. 23 s. (rus.)

11. Wareing J. Covered conductor systems for distribution. EATL Report 5925. 2005. 66 p.

\section{СПИСОК ЛИТЕРАТУРЫ}

1. Rokowska A. Overhead CC lines experience in design, construction and service with reliability assessment in central Europe // Proc. of the Fourth International Covered Conductor Confrerence ICCC. Helsinki, 2000. P. 56-68.

2. Lovrenčić V. Slovene experience about using covered conductors (PAS system) in Medium Voltage Network // Proc. of International Conference on Electricity Distribution (CIRED 2000). Shanghai, 2000. P. 35-48.

3. Wareing J., Ward A. The tracking performance of $50 \mathrm{~mm} 2$ AMO Kraft BLX Triple compared with XLPE (3\% carbon) sheated conductor using helical fittings // EATL Report T3805. 2001. 80 p.

4. Wareing J. Tracking tests on new and old CC samples from Finland and Sweden // EATL Report 5779. 2004. $75 \mathrm{p}$.

5. Yano K., Wareing J. The Japanese experience // EATL Report 4373. 1997.

6. ГОСТ 31946-2012. Провода самонесущие изолированные и защищенные для воздушных линий электропередачи. Общие технические условия. Введ. 2014-01-01. М.: Стандартинформ, 2013. 20 с.

7. Wald D. The use of track resistant XLPE insulation for MV aerial cables // Proc. of Covered Conductor Seminar. Capenhurst, 1996. P. 18-27.

8. Wald D., Campus A. The influence of carbon black in XLPE compounds in MV aerial cables // Proc. of the 1st International Covered Conductor Confrerence ICCC. Capenhurst, 1997. P. 25-36.

9. Соловьев Ю.В., Таджибаев А.И., Назарычев А.Н., Ярмаркин М.К. Анализ технического состояния защищенных проводов линий электропередачи. СПб.: Изд-во ПЭИПК, 2015. 193 с.

10. ГОСТ 17512. Электрооборудование и электроустановки на напряжение 3 кВ и выше. Методы измерения при испытаниях высоким напряжением. - Введ. 1984-01-01. М.: ИПК Изд-во стандартов, 1984. 23 c.

11. Wareing J. Covered conductor systems for distribution // EATL Report 5925. 2005. 66 p. 


\section{СВЕДЕНИЯ ОБ АВТОРАX/AUTHORS}

SOLOVYEV Yurii V.- ALSIB Company Ltd.

12, Michurinskaya St., Saint-Petersburg, 197046.

E-mail: yury.solovyev@yahoo.com

СОЛОВЬЕВ Юрий Владимирович - кандидат технических наук генеральный директор ООО «Компания АЛСИБ».

197046, Санкт-Петербург, ул. Мичуринская, 12.

E-mail: yury.solovyev@yahoo.com

NAZARYTHEV Aleksandr N. - Petersburg Power Engineering Institute of professional development. 23, Aviatsionnaya st., Saint-Petersburg, Russia, 196135.

E-mail: nazarythev@mail.ru

НАЗАРЫЧЕВ Александр Николаевич - доктор технических наук ректор Петербургского энергетического института повышения квалификации.

196135, Санкт-Петербург, ул. Авиационная, 23.

E-mail: nazarythev@mail.ru

TADZHIBAEV Aleksei I. - Petersburg Power Engineering Institute of professional development.

23, Aviatsionnaya st., Saint-Petersburg, 196135.

E-mail: iec@peipk.spb.ru

ТАДЖИБАЕВ Алексей Ибрагимович - доктор технических наук заведующий кафедрой «Диагностика энергетического оборудования» Петербургского энергетического института повышения квалификации.

196135, Санкт-Петербург, Авиационная ул., 23.

E-mail: iec@peipk.spb.ru 